\title{
Minorities and the Symbolic Potential of the Academic Library: Reinventing Tradition
}

\section{Camila A. Alire and Frederick J. Stielow}

\begin{abstract}
Mainstream American colleges and universities face a series of challenges over the recruitment and retention of their minority students. In a theoretical essay with practical examples, a Hispanic library dean and the executive director of one of the nation's largest African American archives argue that the academic library has a special and all too often overlooked role to play in resolving a portion of these difficulties. While acknowledging prior good intentions, they ask the reader to add critical and semiological perspectives of their institutions to this equation. The university and its library are signs of advancement, yet they can also project an alien, elitist, and previously forbidden goal to minorities. The academic library's potential may actually rest on an understanding of its own symbolic power and the librarian's proactive willingness to reinvent tradition to include minorities and their heritages as an integral part of the academic environment.
\end{abstract}

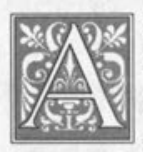

ffirmative action," "Afro-centric," "cultural studies," "diversity," "multiculturalism"the terms pour on librarians from the literature, conferences, and interminable meetings. Mainstream colleges and universities are embracing a wave of minority recruits and interests. The reasons are easy to discern. In the decades since Brown v. Board of Education, America has attacked the visible patterns of Jim Crow. While problems remain, prior admission hurdles have been attacked, and academia has awakened to a complex problem with a long history.

Economics and numbers also tell an inevitable tale. Even with admitted undercounting, the 1990 U.S. Census reported that of the two largest minorities, African Americans increased by 13.2 percent and Hispanics by an exceptional 53 percent since 1980 . By the turn of the century, one-third of the country will be minority with the highest concentration among the young - the main academic student pool. Indeed, minorities have the potential to become the majority of college students. ${ }^{1}$

Ethnic or racial awareness units, student organizations, and special studies programs are now ubiquitous. Recruiters for students, faculty, and staff scramble for the best and brightest. Campuses across the nation recognize the need to

Camila A. Alire is Dean/Director of the Auraria Library at the University of Colorado at Denver; e-mail: calire@castle.cudenver.edu. Frederick J. Stielow is Executive Director at Amistad Research Center, Tilton Hall, Tulane University; e-mail: stielow@mailhost.tcs.tulane.edu. 
fight against racial slurs and sensitize their communities. Yet, the new awareness and infrastructure have frequently come up short. Minority students often remain apart. They continue to complain against the weight of perceived paternalism. Matters are further complicated by the Byzantine administrative reality of modern higher education. On the one hand, some may resist any change as an affront to the sacred past. They view ethnic studies programs and minority affairs offices as mere tokens and not worthy of integration with the tried and true mission of the school. On the other hand, academic departments and disciplines wrangle over who is actually or spiritually qualified to teach and decode discourse for the student. Indeed, the new programs and offices may guard their turf against other possible contributors on campus. $^{2}$

To Cornell West and other modern Black intellectuals, the drive for a safe and humane nation has encountered potholes and the mixed legacy of the Civil Rights Movement. As concerned academic librarians, scholars, and representatives of a minority and a minority institution, the authors suggest that the campus library provides exceptional opportunities for repaving and reinventing. Given the complexities, campus politics, and occasionally the vituperative nature of the debate, they must warn the reader that such a task is not easy and may prove disconcerting. Librarians will need to be proactive to market this potential and circumvent potential bureaucratic roadblocks. Success may depend on an ability to understand and manipulate one's institutional heritage and symbolism - a willingness to reinvent tradition. ${ }^{3}$

\section{Cannibals and Tartans}

There are a number of lessons to be learned from the disciplines and clientele that librarians serve. Semiologist Roland Barthes shows how everyday activities, institutions, and vocabulary hide the most crucial insights to human behavior. To Barthes, the obvious factors are often the most difficult to understand or deconstruct and may contain their own mixed legacies. Only after decades of struggle and education, for instance, are people able to comprehend the damages of racial stereotyping. Once fashionable minstrel shows and pickaninny lawn statues are no longer acceptable. Yet, people all still live with their residues and other deeply imbedded misconceptions. How many are aware of images and stories of ritual cannibalism in Africa, but can anyone name an African tribal group that actually practiced such rites? ${ }^{4}$

The power of the cannibalism metaphor is hard to dismiss but equally difficult to overcome. Interpretations of the same events may lead to confusing struggles between those who defend their traditional beliefs versus those with very different viewpoints. Critical theorists and postmodernists are joined by minorities in combating what had been accepted as neutral and normal. Consequently, the names of school mascots devolve into controversy; and the quincentenary of Christopher Columbus becomes a battleground over discovery versus conquests and genocide. ${ }^{5}$ In the words of Native American historian Donald Grinde Jr., minority people have the right to question the established perspective. He states:

With this mentality, Native American people often find their history imprisoned by the rhetoric and scholarly inventions of empire. As technicians of American nationalism, many American historians consciously and unconsciously perpetuate these conceptual "truths" and inventions of empire in their discourses on United States history. Much of the tension surrounding the emergence of American Indian studies and history in the academy is the product of an intellectual tra- 
dition that rationalized and "legalized" European conquest. Thus these invented intellectual realities of the last five centuries stand in the way of the creation of a meaningful discourse between Native and nonNative peoples in the Americas. ${ }^{6}$

The entire Western canon is under attack and has only recently expanded to acknowledge contributions from Islam, subSaharan Africa, the Chinese court, and the Incan and Aztec civilizations.

Even a simple review of older American textbooks will confirm that American students were force-fed anti-Spanish black legends and tales of evil Mexicans. These helped justify our Manifest Destiny. Although often subtle, the forces of perverted traditionalism have played devastating roles from the deliberate manipulations of cultural icons and institutions in Nazi Germany and the Soviet Union to the struggles in Yugoslavia today. As the great Marxist thinker Antonio Gramsci and historian/philosopher Michel Foucault argue, even seemingly benign cultural agencies may be party to distortions and a "history of details" of state power. ${ }^{7}$

These external voices call us to examine the history and image of the library across time. There is some good news. From the beginning of written time, the library has served as a mark of wisdom, civilization, and tradition. This institution played, and continues to play, a positive role as a mark of culture and advancement.

With the rise of the printing revolution and concomitant western expansionism, the institution of the library took on different functions and notions. State libraries and archives began to appear and signaled the advances of their civilization. The Vatican Library and Spanish Escorial set the original tone, but the crucial era began with the French Bibliothéque Nationale and the wave of nationalism released by Napoleon in the early nine- teenth century. Such institutions emerged as physical monuments in grandeur and scope-part of a celebratory craze in the West.

Americans took this one step further and democratized the symbol. Melvil Dewey and Andrew Carnegie helped create the new public library as a municipal icon-one which came to denote the arrival of a truly progressive municipality. ${ }^{8}$

Library historian Michael Harris, however, demonstrated that even the saintly American public library movement can be viewed through the lenses of paternalism and social control. While certainly a civic good, the public library was nevertheless part of a general effort to Americanize new immigrants and make them better workers. From ongoing research, the authors can also establish the rise of state archives and other cultural agencies in the South. Their establishment was part and parcel of memorializing the Confederacy and coincided with the rise of Jim Crow.

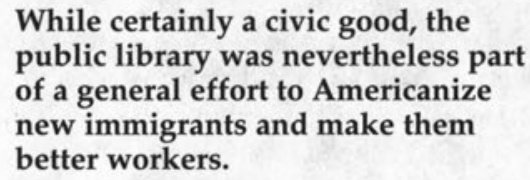

While certainly a civic good, the public library was nevertheless part of a general effort to Americanize new immigrants and make them better workers.

The problem, too, is what was left out. It is difficult to identify nationally significant African American or other minority library monuments outside of the historically Black colleges and the Schomburg of the New York Public Library until very recent times. Additionally, the Amistad Research Center is acknowledged as a pioneer but was only founded in 1966 as part of a minor wave of similar recognition. ${ }^{9}$

American universities and their libraries were included in nationalistic campaigns. As revisionist historians have documented, these bodies were tools in the general push to indoctrinate African Americans, Hispanics, and other immi- 
grants - to bring them up to the American standard. ${ }^{10}$ Academic libraries could do no better than reflect the paternalism of their institutions and the seemingly racist scholarship of the era. In 1886, for example, Herbert Baxter Adams argued for an expanded view of the academic library as:

Part of a great democratic movement belonging to the 19th century; it is an organized effort on the part of university men to raise, uplift the masses, to carry out from academic cloisters the fruits of higher learning. ${ }^{11}$

Despite the best of all intentions, Adams's American universities enforced, and some continued to champion, a very narrow canon from that era-a canon that whitened or ignored non-WASP contributors. Consequently, minorities who were considered outsiders trying to achieve the American Dream through mainstream education had to pass through doors that implicitly alienated them from their cultural traditions. Can anyone question the discomfort of such individuals who enter the hallowed halls of the library? It is clear why such facilities were often the targets for radical takeovers in the $1960 \mathrm{~s}^{12}$

Minorities and those championing the entrance of different viewpoints focused on the emblematic role of the library. This focus makes for some interesting possibilities. Historically, they are quite accurate about the symbolism. Colleges and universities literally took root from their libraries. Libraries provided the first permanent infrastructure and names like the Sorbonne and Harvard.

The academic library emerged as the psychological soul of the university. However, the institution itself was not set in stone. Traditions changed and were created. The sacred temples of classicism that excluded undergraduates gave way to the student laboratory and research center which occurred largely within the last hundred years. The academic library was part of this new university movement toward practical training and empiricism. As exemplified by the University of Illinois and replicated elsewhere, the academic library emerged as a prerequisite sign in this transformation. ${ }^{13}$

In 1902, James Hulme Canfield, one of the great popularizers of the academic library movement, argued that the library had become the "heart" of a massive change:

The changes which have come in all phases of college life during the last half-century constitute almost a revolution. But of all these, the changes in library constituency and in library management are the most notable. Fifty years ago the college library was almost an aside in education. Indeed, it was like the sentence which we enclose in brackets: to be read in a low tone, or to be slurred over hastily, or even to be entirely omitted without making any serious change in the sense. ${ }^{14}$

History reveals that many of our hallowed academic traditions are less than sacrosanct and often of quite recent vintage. Even the medieval caps, gowns, and hoods seen at graduation ceremonies were generally adopted in their present forms only earlier in this century. As Eric Hobsbawn demonstrates in The Invention of Tradition, other traditional signs of identity and advancement were actually created at roughly the same time as library and racial myths took hold. For example, the sacred Scottish tartan emerged only in the eighteenth century as part of a deliberate sales campaign by textile manufacturers.

Unlike the implicit denigration of cannibalism, the tartans became powerful and lasting symbols that helped affirm both individual tribal identity and a national identity for a country in turmoil. ${ }^{15}$ The success of the tartans and the impor- 
tance of graduation regalia are appropriate metaphors and precedents for the active creation of new traditions - traditions that need to be expanded to respect and include minorities. These symbols can be models in a drive to reinvent tradition to encompass minority perspectives through the academic library.

\section{Practical Applications}

Given the practical considerations and the historical legacy, how should librarians in traditionally White institutions act? Some of the answers are obvious and have been around for some time but can take on new possibilities with a different viewpoint. For example, the authors agree with the importance of hiring minority librarians. They applaud the field and its longstanding attempts to increase the number of minority professionals. Efforts, while not a total success, certainly leave libraries better off than many other fields in academe. However, does not this very success provide libraries with a bargaining chip for administrations searching for diversity in the general faculty? Couldn't this effort also provide vital role models for minority students? ${ }^{16}$

The hiring of minority student workers provides another illustration of a practical vehicle. At the University of Colorado-Boulder, library dean Jim Williams called on university officials for an increase in the library's student budget specifically to hire minority students as reference assistants in the library. The program demonstrated a commitment to minority student retention on the library's part and also on the campus administration's part. Not only has the library become more receptive to minority students, but these students are also being recognized as a valuable resource on campus. In turn, those minority students with minimal prior exposure to libraries and study skills seem to have benefited by becoming better prepared for college studies. In addition, the library faculty and staff gained valuable experience in estab- lishing a workplace that is sensitive to serving the needs of minority users.

Library management should be especially proactive in campus efforts to recruit minority students. The University of Colorado's system has very successful precollegiate programs on three of its campuses. The university brings economically disadvantaged minority high school students on campus each summer from their sophomore year until graduation.

The Auraria Library serving the University of Colorado at Denver offers a specialized library instruction course designed to prepare these students for success in high school and prepare them for

In addition, library faculty and staff gained valuable experience in establishing a workplace that is sensitive to serving the needs of minority users.

collegiate work. Efforts like this serve as a strong recruiting mechanism. Tracking suggests that minority students who are treated well and respected are very likely to choose the institution where they are welcomed and valued.

A good first impression may be the deciding factor that prospective students use to make their college or university selections. One of the author's personal experiences as a first-generation matriculant certainly indicates that first-generation and/or minority students may feel estranged from even entering the doors of most academic libraries.

What clues can minority students and their parents use to indicate that they are welcomed in the library? Federal legislation forces libraries to deal with the physically handicapped minority, but what do they do for those with English as a second language? Are there other hidden barriers to minority use? How do these tie to the frequently overlooked, yet vital goals of minority student retention and 
the making of a pool of satisfied alumni and potential donors?

Positive endeavors call for a sensitized staff-a group which can give up paternalism or strict adherence to past traditions for a dialogue with those bringing new cultures and vistas to campus. Exhibits, bibliographic instruction, and other outreach efforts, for example, are necessary components that may call for tailoring. Bibliographic instruction may require sensitizing in terms of its language use and sample subjects.

The same is true of exhibits. Libraries must be willing to take risks in hosting exhibits that could spark intellectual debate relative to the treatment of minorities on and off campus. The Amistad Research Center, for example, joined Tulane University's Office of Multicultural Affairs in a celebration of the thirtieth anniversary of Tulane's desegregation. To do this meant exposing the racism that preceded 1963 and may still exist on campus. To do any less would have trivialized the celebration.

Librarians should also understand that they will incur new and equally essential services for minority clientele. Multicultural outreach is not only necessary, but can also be viewed as a marketable contribution toward the university's teaching mission. The burgeoning number of minority studies and cultural awareness programs obviously need to be supported by library collections. The questions for collection development, however, are heightened because of a likely pattern of historical oversights that may call for redress. ${ }^{17}$

Library management is well advised to see the potential in recognizing other minority efforts and should not view such efforts as an extra burden or game-one which takes away from sanctified tradition and essential services. Prior academic traditions and the current canon are not sacrosanct or absolute truth. They arose from a particular time and set of constantly changing standards, but they do not escape the prejudices of the past. Again, libraries do not need to strike the earlier standards; they need only to include some additions and different viewpoints. For instance, can twentieth-century art be appreciated or analyzed without acknowledging its ties to African models? The same could be said about dance, music, and literature.

Libraries cannot afford to ignore the power and symbolism afforded by the ongoing information technology revolution. As the American Library Association and other concerned groups have indicated, it is vital that minorities not be left behind on the information highway. Minorities are actively seeking remedies. For example, the recent Africana libraries represented at the Information Age Conference held at the Schomburg Library underscored the need and ongoing efforts for the minority community to be included in the national information infrastructure. However, historically Black colleges and universities and most minority cultural institutions are underfunded and not linked electronically.

Only because of its position within a mainstream university, the Amistad Research Center succeeded in leading the way using technology. The center launched its gopher in mid-1994 and has gone into Mosaic. The design of these resources includes a consciousness of symbolism. The selection of icons used in the screen presentation is drawn from and reflects African American and African art. The use of these icons will serve only to promote the self-esteem of African American users of the collection no matter their age. $^{18}$

Service to minorities simply implies a proactive stance and the need for some redress for at least a century of oversights. The authors maintain that good intentions alone will not suffice. The psychological impact of the library and librarians as cultural stewards cannot be ignored. A clientele, previously denied its monuments and intimidated with 
thoughts that it could not compete, may need extra attention to know that it is welcomed. Academic librarians may have to reach out to minority students and alumni groups. They must be willing to work with and inform them about the new commitment.

Reference and bibliographic instruction librarians should be major players, but one of the keys may be in special collections departments. The last are the most semiologically intense arenas and the primary bastion of the traditions that have ignored minorities in the past. Yet, special collections also provide the easiest target to focus management attention and to garner positive publicity. Some might even follow the lead of Harvard University in creating its W. E. B. DuBois Center, or Tulane University in offering to house and partially underwrite the Amistad with its 10,000,000-document collection. Most will settle for smaller concentrations and/or renamings in the university archives, special collections department, or perhaps an area reserved for a specific ethnic/racial book collection.

However, even on the most practical level, how will library managers deal with an expanded role for special collections, which are themselves often ignored and considered peripheral in modern academic libraries? Does a library want to bring a potentially competing body, like the Amistad, to campus? More importantly, where can a library find the additional expertise and budget to address programmatic development? How can a library avoid censorship and, at the same time, avoid the faux pas of uninformed paternalism?

Salvation will not be instantaneous, and problems obviously can arise from such extensions. Libraries must deal with entrenched forces and symbols. Diversity training, especially that which includes a semiological component, is a partial solution. Staff-minorities and nonminorities alike - should also be involved in the planning for multicultural programs as a recognized part of the library's basic mission.

\section{Suggestions for Action}

Throughout this article, the authors have referred to possible ways for proactive action by academic libraries and librarians. Additional concrete suggestions for

\section{Successful mentoring of minority library faculty can make the differ- ence in their success not only in their primary job but also in their research and service requirements.}

library action include, but are not limited to, the following.

In the area of bibliographic instruction, the librarians could specifically design. instruction for minority-related programs such as ethnic studies, minority precollegiate, and ESL. In addition, multicultural courses that are designed for specific subject disciplines could benefit from a library instruction component. No matter the program or the format, library instruction should include vivid examples in the program that reflect an integration of cultural awareness, sensitivity, and appreciation.

Other suggestions for academic library action relate to personnel. Libraries must aggressively hire minority librarians, staff, and student workers. Diversity training of staff is a must to prepare them better to work effectively with students, faculty, and coworkers who are different from them. However, attempts by the academic library should be made to integrate diversity throughout the library's operations-policies, procedures, collections, and services. How many academic libraries have adopted a policy statement that deals specifically with services to their minority constituents?

Mentoring is another suggestion for action. Successful mentoring, formally or informally, of minority students can keep them in college; recruit them into the li- 
brary profession; and retrain those who are already working in academe. Successful mentoring of minority library faculty can make the difference in their success not only in their primary job but also in their research and service requirements.

Another suggestion for action relates to programming. The academic library should take the lead in hosting campus programs, colloquia, or author series that deal directly with minorities and minority issues. Related to this is the possibility of the academic library hosting minority-related exhibits, art displays, and book/poster displays.

Finally, developing an academic library collection which reflects diversity in the academy-students and faculty, curriculum, research, special collections, and so forth-should not be the exception but the rule. Academic library collection policies should include a statement that demonstrates an intent to collect in support of diversity throughout the academy's curriculum.

\section{Conclusions}

Problems aside, minority students are here, and vocal minority student bodies will speak out. They need to know that the library is also theirs. They need to be convinced that what was seen as an exclusively white domain can be a people's institution.

The new student demographics demand that they have materials that speak to both their cultural and educational needs. Libraries content on resting on the status quo are not only failing their mis- sion, but are also likely to create a point of contention for their universities in the future. If ignoring the question is not the answer, perhaps librarians might follow normal management principles and plan to meet the challenge. Such exploration can also prove a valuable selling point when pleading the library's fiscal case with university administrators.

The library stands as a universal symbol of knowledge. This symbol can speak to people of all races and creeds. This institution can play a unique role in reinventing tradition.

Practically, most libraries can and should insure that their collection policies reflect and champion a minority presence. Librarians also have a cultural stewardship. They need to deal with the symbolic and practical roles of their institution as they relate to the socialization and recruitment for a new minority-conscious academy. Indeed, increasing staff diversity and developing the potential for minority students to excel within the key traditional symbol of the university should be trumpeted.

In sum, the authors hope to have raised some questions, provoked some thought, and provided some historical context. Academic and other librarians need to prepare for coming demographic inevitabilities. What began as White, elitist institutions will require rethinking and a reworking of their images. Libraries and librarians cannot rest on their past laurels. Librarians must address the symbolic and actual state of their facilities and try to reinvent a positive tradition for a burgeoning minority clientele.

\section{Notes}

1. Camila A. Alire, "The Community College Library's Role in the Recruitment and Retention of Minority Students: 'Ez No My Job, Man,'" Colorado Libraries 17 (Sept. 1991): 5.

2. The academic debates can be seen sprinkled throughout the pages of the Chronicle of Higher Education, as well as the academic journals and even such staid newsletters as Perspectives of the American Historical Association, which over the past two years has featured an ongoing debate on who teaches.

3. Cornell West, Race Matters (Boston: Beacon Pr., 1993). Although this book is essentially a "think piece," it is based on practical experience and ongoing research-for example, a 1994 
Archival Research Fellowship at the Bentley Library, University of Michigan, to do research on the semiology of archives and their role for minorities.

4. Roland Barthes, Mythologies (New York: Hill \& Wang, 1972); Patricia A. Turner, I Heard It Through the Grapevine: Rumor in African American Culture (Berkeley: Univ. of California Pr., 1993), Chapter 1, "Cannibalism."

5. For example, see Bill Bigelow, Barbara Miner, and Bob Peterson, eds., Rethinking Columbus: Teaching about the 500th Anniversary of Columbus's Arrival in America (Milwaukee: Rethinking Schools, 1991).

6. Donald A. Grinde Jr., "Teaching American Indian History: A Native American Voice," Perspectives 32 (Sept. 1994): 12.

7. Much of the "cutting edge" of modern social criticism stems from the thoughts of Nietzsche. Gramsci is another key figure who, in his Letters from Prison, commented brilliantly on the failure of communism in the U.S. through its magnificent abilities to co-opt opposition through material goods and cultural institutions. For the most-cited recent critic, see Michel Foucault, Madness and Civilization (New York: Pantheon, 1967).

8. James Clifford, The Predicament of Culture: Twentieth-Century Ethnography, Literature, and Art (Cambridge: Harvard Univ. Pr., 1988); Robert S. Martin, ed., Carnegie Denied (Westport, Conn.: Greenwood Pr., 1993): 35-52.

9. Michael Harris, "The Purpose of the American Library," Library Journal 98 (1973): 2,509-14 (easily the most cited American library history article); see also Frederick Stielow, "Censorship in the Early Professionalization of American Libraries," Journal of Library History 18 (1983): 3654; the Southern example is based on an ongoing semiological investigation of archives and their monument functions for minorities, which was partially funded by a 1994 Summer Archival Research Fellowship at the Bentley Library of the University of Michigan.

10. Lawrence Vesey, The Emergency of the American University (Chicago: Univ. of Chicago Pr., 1967); Herbert Gutman, Work, Culture, and Society in Industrializing America (New York: Knopf, 1976); Michael Kammen, Class, Bureaucracy, and Schools (New York: Praeger, 1975).

11. Herbert Baxter Adams, "University Extension," Library Journal 15 (1886): 121.

12. Mary Lee Bundy and Fred Stielow, eds., Activism in American Librarianship, 1962-1973 (Westport, Conn.: Greenwood Pr., 1987).

13. Frederick Stielow, "Storehouse, House, or Adjunct?: Toward a Theory of the Development of College and University Libraries," Current Studies in Librarianship 5 (1981): 41-50.

14. James Hulme Canfield, "The College Library," Outlook 71 (May 1902): 248-50.

15. Eric Hobsbawn, The Invention of Tradition (Cambridge, England: Cambridge Univ. Pr., 1992); the Torah of the Jewish people provides another powerful symbol capable of synthesizing and uniting a disparate people over time.

16. Kristin H. Gerhard and Jeanne M. K. Boydston, "A Library Committee on Diversity and its Role in a Library Diversity Program," College \& Research Libraries 54 (July 1993): 335-43; or the coverage in "Racial and Ethnic Diversity: Information Exchange," College and Research Libraries News; Final Report of the Association of College and Research Libraries Task Force on Recruitment and Retention of Underrepresented Minorities (Chicago: ACRL, 1992), provides a solid overview of practical measures, but essentially overlooks the semiological issues.

17. Daryl G. Smith, The Challenge of Diversity: Involvement or Alienation in the Academy (Washington, D.C.: School of Education and Human Development, George Washington Univ., 1989); "The Luring of Black Students," U.S. News \& World Report (March 15, 1993), is an example that speaks in generally deprecating tones about perceived excesses in the recruitment of Black college matriculants.

18. The need for including electronic technology and the leadership role the Amistad played in adapting the technology for its users were discussed at the Africana Libraries in the Information Age Conference hosted by the Schomburg Library, New York City, January 1995. 


\section{The State}

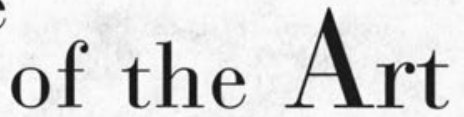

...working

smart

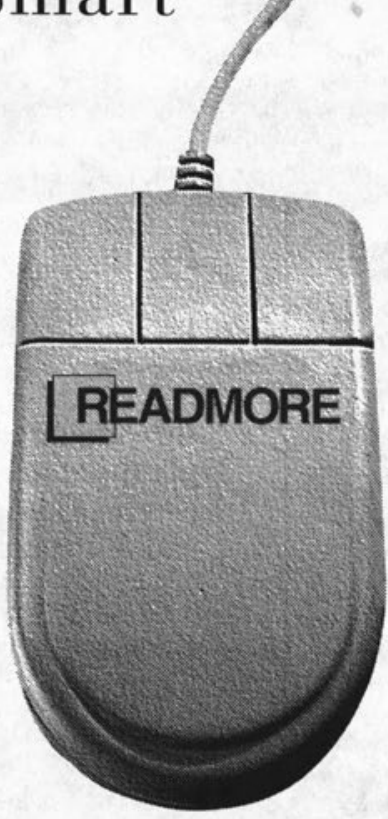

Leaders in the Information Industry providing subscription services, article delivery and library automation software.

- REMo Mouse driven serials management system.

- Ross Online ordering, claiming and searching of journal and publisher databases.

- Renewal Express PC-based system to analyze current serials holdings and plan for the future collection development.

- Financial Planner Lotus formatted worksheet to analyze previous spending history and plan future budget allocations.

- UnCover The fastest most comprehensive service for fax delivery of journal articles available today.

- BACKSERV An Internet list devoted to the informal exchange of serial back issues among libraries.

\section{Readmore Academic Services}

700 Black Horse Pike, Suite 207

Blackwood, NJ 08012

Phone: 1-800-645-6595

Fax: 609-227-8322 